\title{
学校教育と戦後日本の社会意識の民主化
}

\section{吉川徹*・轟 亮**}

\section{1. 戦後日本の社会意識の民主化}

戦後の日本社会においては，ポッダム宣言に「日本國政府八日本國國民八間二於ヶ ル民主主義的㑯向ノ復活強化二對スル一切ノ障破习除去スベシ」とあるとおり, 非軍 事化とともに，諸制度の民主化とそれによる社会意識の民主化が第 1 の社会的要請と された。教育改革は GHQによる民主化政策の重要な側面として位置づけられている が，それは単なる学制上の改革にとどまらず，学校教育の基本理念のレベルからの民 主的変革を遂行し，日本社会における社会意識の民主化を実現することを目的として いた。またこの時期，社会意識論の見地から大塚久雄（1948）は「吾が國民䍃が低い 近代以前的エトスを捨て去って，近代的・民主的人間類型に打ち出されるといふこと は如何にして可能であらうか」という問題を,「何よりもまづ最も広義での教育の問題 である」(10頁) として, やはり社会意識の民主化実現の第 1 の手段が教育にあること を示している。

以来50年が経過し，最初に新制の教育課程の小学校に入学した世代ですら，すでに 祖父・祖母というライフ・ステージにさしかかり，戦前の旧制教育を受けた世代は 徐々に産業社会の主要部分から退出しつつある。学校教育が次世代に何ほどかの道徳 的特質を伝達し，それが永続的なパーソナリティとして変更されずに残存するとする ならば，戦後の教育改革が目的としていた社会意識の民主化は，戦前の軍国主義的な 旧制教育の残映を保持する世代のこのような人口学的な退出によって, ようやく完成 しつつあるとみなせるだろう。こうした経緯からいって, 現代日本社会の社会意識を

*静岡大学 **大阪大学大学院 
考えるうえで，いまわれわれは名実ともにひとつの転換点を迎えている。すなわち戦 後が生み出した教育制度の社会的機能を適切に評価しうる時点をついに迎えたと考え られるのである。そこで本稿では，現代日本社会にあえて「戦後」という分析枠組を 設定し, 戦後日本社会の社会意識が本当に当初の理念にあるとおりの「民主化」を成 し遂げたのか，またその䞶勢に学校教育は期待された機能をどの程度果たしたのか， という問題について, 計量分析の結果をもとに検討する。

\section{2. 社会意識の民主化とその指標}

社会意識の民主化の動向を論じるために，まず民主主義的な社会意識とは何かとい うことを確定する必要がある。価值観の多様化・多元化が指摘される今日の状況にお いては，「民主主義的社会意識」はいかにも広範かつ多義的で捉えにくい概念である。 しかしながら，狭い意味で戦後とみなされる1950年代までの時期においては, 社会意 識の民主化とは，戦後日本国民が天皇制イデオロギーに代表される旧意識あるいは醇 風美俗を捨て去り，近代的エートスを獲得することを意味していた（大塚前掲書，日 高 1960, 城戸 1970)。そこでは社会意識の民主化は, 空虚な喧伝ではなく, 近代的 エートスの獲得という明確な方向性をむって理解されていたのである。さらにこの近 代的エートスの具体的な内容は, 同様にファシズムの歴史的事実への深い反省から発 展した大䍃社会論の主要なテーマとしても展開されている。すなわち民主主義一反民 主主義の基軸として, よく知られるところの権威主義的性格である（城戸・杉 1954)。アドルノらのバークレーグループの研究では, 反民主的な政治的宣伝に引き付 けられやすい性格を索出する過程で, 大衆に広く潜在する社会意識として権威主義的 性格が計量的に検出されている（アドルノ他抄訳 1980)。それ以後, 民主主義的社会 意識はその対極の権威主義的性格を用いることによって指標化され, 数多くの実証研 究が蓄積されてきた。そしてこの指標は，政治的態度の潜在的な規定要因として民主 主義的社会意識の重要な中枢をなすと目されてきている。伝統的権威を巧妙に利用し て軍国主義が展開されたという歴史的背景を有する日本社会においては，この権威主 義的性格が, 伝統的・因習的価値, 旧意識あるいは醇風美俗と呼ばれたものと意識構 造上，不可分に融合することが指摘される。したがってこの当時においては，社会意 識の民主化とは, こうした伝統主義＝権威主義的傾向を反転・修正する過程を意味し ていたのである。

くり返しになるが，われわれが生活する90年代の日本社会においてはもはや，民主 主義的な社会意識に関するこうした理解の様式には, 唯一無二のものであったり網羅 
学校教育と戦後日本の社会意識の民主化

的なものであることを必ずしも期待できない。だがこのような概念規定をもとにした 研究が戦後日本の民主主義的社会意識を論じる上で，少なくともひとつの重要な基軸 を提示していることは確かである。そこで本稿では上述の研究の蓄積を鑑みた上で, 権威主義的態度尺度（正確にはその対極）を社会意識の民主化の指標と捉えて考察を 加えることにする。

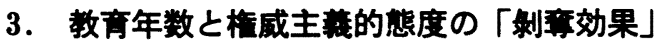

直井道子（1988）は，1985年 SSM 調查の男性 A 票を用いて，成人有職男性の権威 主義的態度の分布状況と形成要因を検討している（表 1 参照)。そこでは, 権威主義的 傾向には職業的地位，年齢，学歴などによって有意な差がみられるが，その分布を形 成する要因は主として学歴と年齢であることが解明されている。このうちの学歴の効 果は，高学歴であるほど権威主義的傾向は低下するという方向を示す。この関係は権 威主義的傾向が学校教育による認知的能力の向上によって低下するという直接的な関 係を示していると判断できる。

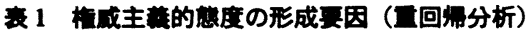

\begin{tabular}{|c|c|}
\hline 説明变数 & 標準偏回㷌係数 $\beta$ \\
\hline 学 歴 & $-.238^{* *}$ \\
\hline 職業威信 & 0.029 \\
\hline 年龄 & $0.221^{* *}$ \\
\hline 都市規模 & 0.031 \\
\hline
\end{tabular}

直井道子 (1988) 234頁から一部を售正して再䟿

この研究を受けて，吉川（1996）は1990年代の学校教育と青少年の権威主義的態度 の形成について，さらに踏み込んだ計量研究を行ない，次のようなメカニズムを解明 している。それぞれの青少年に家庭において両親から伝達された権威主義的傾向は, 学校教育による社会化と心理的発達によって知的能力が伸長するととすに，つまり年 齢（=学年）が上㫒するととるに低下する。ところがその一方で，現代日本社会の学 校教育は，厳しい校則による生活指導，あるいは教師による授業内外の厳格な管理な どの権威主義を体現する教育条件によって，権威主義的態度を付与的に形成する（プ ラスの効果をもつ）側面をも確実に有している。つまり社会意識の民主化という機能 に関してみた場合, 学校教育は一方で権威主義的傾向を剥奪しながら, 他方で付与す るという「諸刃の剣」の性質をもつのである。そして1990年代の日本社会の教育環境 
においては，2つの効果の相殺の結果として表出しているのは，学校教育が権威主義 的傾向を低下させる「剝奪効果」である。

このメカニズムにおいて, 学校教育が権威主義的価値の伝達をより強力に推進した 場合, 学校教育による権威主義的㑯向の剝薪効果が小さくなる, さらには付与的効果 に転じることも十分にありうるだろう。こうした仮説を日本社会の歴史的経緯に重ね て展開するならば，旧制教育制度において皇国史観，全体主義的道徳性などを内容と する軍国主義教育を受けた世代と，新制教育制度において意識的に企図された民主主

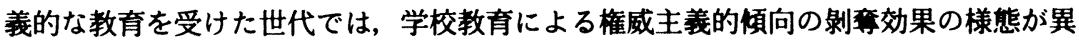
なると考えられる。実際に直井の先行研究では，年龄と権威主義的㑯向の間には年齢 が高いほど権威主義的であるという直接的な関係が明らかになっているが，このよう な世代間格差を生み出した要因として, 戦前・戦後の教育の質の根本的な差異が考え られないだろうか。そこで学校教育の権威主義的態度の剝薪果, つまり民主化の効 果が，諸個人の受けた教育の質（教育制度の新・旧）によってどのように異なるかと いう問題をみていくことにする。ただし，それぞれの世代の教育現場の諸条件とその 社会化の効果に関する直接的な計量データが存在しないため, それぞれの学校教育の 機能の生きたダイナミズムを実証的に検討することはできない。したがってここで は，現代社会を構成する成人の社会意識に残存する学校教育の影䇾を，社会意識論の 観点から検討することになる。

\section{4. データ}

ここでは1985年 SSM 調查の男性 A 票を分析する（有効回答数1,239サンプル)。こ のデータは1915（大正 4) 年から1965（昭和40）年までの生年の男性を母集団とするも のである。つまり 1996 (平成 8) 年現在では31歳から80歳となる標本である。このこと は，このデータが単に1980年代の社会の構成員をよく代表しており現代の社会意識を 検討するのに適切であるというだけではなく，戦前に最終学歴を達成した人から，旧 制の初等中等教育から新制への転換を経験した人，そして戦後の新制教育のみを受け た人までをバランスよく含んでいることを意味する。それゆえにこの調査データは， ここでのわれわれの関心に対して，極めて適切なそしておそらく最後のあのであると いうことができる(1)。

\section{5. 民主主韻的社会意識の測定}

社会意識の民主化の指標として用いる権威主義的態度尺度は以下の 6 項目に対する 
「賛成」「どちらとあいえない」「反対」の 3 分位の回答から測定される。

（1）権威ある人々にはつねに敬意を払わなければならない。

（2）以前からなされてきたやり方を守ることが，最上の結果を生む。

(3) 子どあのしつけで一番大切なことは，両親に対する絶対服従である。

(4) 目上の人には，たとえ正しくないと思っても従わなければならない。

(5) 伝統や慣習にしたがったやり方に疑問を持つ人は，結局は問題を引きおこすこ とになる。

(6) この複雑な世の中で何をなすべきか知る一番よい方法は，指導者や専門家に頼 ることである。

これらはいずれも，権威主義的態度尺度の測定に最もよく用いられてきたものであ る (Kohn and Schooler 1983, 直井優 1987, 直井道子前揭論文, 白倉・岩本 1990)。ここでは上記 6 項目に対して主成分分析を行ない，表 2，表 3 の結果を得た。 そして, 各項目が均質な因子負荷量をもっており, 十分な寄与率が得られた第 1 主成 分を因子得点化した。この因子得点をさらに偏差値計算で通常用いられる平均 50 , 標 準偏差10の標準化尺度に変換し, これを権威主義得点として分析に用いることにす る。なお,これは同一のデータを用いた直井の先行研究における権威主義的伝統主義 とほぼ同義の尺度と理解される。

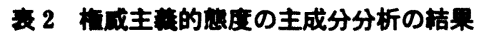

\begin{tabular}{|c|c|c|}
\hline 因 & 固 有 值 & 寄与率 \% \\
\hline 第 1 主成分 & 2.183 & 36.4 \\
第 2 主成分 & .911 & 15.2 \\
第 3 主成分 & .838 & 14.0 \\
第 4 主成分 & (以下略) & (以下略) \\
第 5 主成分 & & \\
第 6 主成分 & & \\
\hline 計 & 6.0 & 100.0 \\
\hline
\end{tabular}

表 3 第 1 因子に対する頜荷笡

\begin{tabular}{|c|c|}
\hline 変 & 因子負荷量 \\
\hline (1)権威ある人々に敬意 & .571 \\
\hline (2)以前からなされてきたやり方を守る & .644 \\
\hline (3)両親に対する絶対服従 & .665 \\
\hline (4)目上のあのに従う & .494 \\
\hline (5)伝統顷習にしたがったやり方をとる & .631 \\
\hline (6)指導者や尃門家に頼る & .598 \\
\hline
\end{tabular}




\section{6. 分 析}

はじめに, 対象者の達成学歴別の権威主義得点を確認しておく（表 4)。一見して権 威主義得点が, 新制学歴達成者と比べ旧制学歴達成者において相対的に高いことがわ かる。また旧制学歴内でも新制学歴内でも, 高学歴であるほど権威主義得点が低く なっており, 教育年数による権威主義的傾向の「㔀奪効果」が確認できる。ただし, 旧制では高学歴エリートとされる旧制高校の学歴達成者でさえ, その権威主義得点は ようやく新制中学校卒業者と同程度でしかない。したがって「戦前の高等教育はリべ ラルだった」という言説は，あくまで旧制学歴達成者間で比較した結果を述べたにす ぎず，新制教育を受けた世代と比較した場合には権威主義得点は必ずしも低くはない ということがわかる。この表の示す数值は, 直井道子の先行研究で指摘された, 権威 主義的態度に対する教育年数と年龄の効果が, 学歷と世代（乞学校教育制度の新・旧） の差異として表出することを示している。

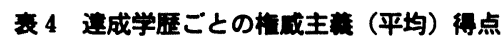

\begin{tabular}{|c|c|c|c|}
\hline 学 歴 & 平 均 & 標 準 偏 差 & サンプル数 \\
\hline 旧制䙳常小学校 & 55.50 & 10.333 & 38 \\
旧制高等小学校 & 57.12 & 9.873 & 151 \\
旧制中学・奏業学校・師籍学校 & 51.03 & 9.392 & 66 \\
旧制高校・高専 & 52.67 & 12.056 & 24 \\
旧制大学 & 50.39 & 9.183 & 14 \\
\hline 新制中学校 & 52.48 & 9.684 & 188 \\
新制高校 & 48.26 & 8.951 & 433 \\
新制短大・高専 & 47.19 & 9.267 & 28 \\
新制大学 & 45.50 & 8.743 & 234 \\
\hline 全 & 50.00 & 10.000 & 1176 \\
\hline
\end{tabular}

eta $=.375$

Sig. $F \leqq 5 \%$

次に, 標本の学歴を初等学歴達成者と中・高等学歴達成者に分類し, 生年世代 (5 年 ごと）別に権威主義得点の推移をグラフであらわした（図 1)。まず標本全体の権威主 義得点の世代による推移は, 直井道子の分析結果から予測されるとおり, 右下がりの 傾向を示している。ただし1940年生まれまでの世代では直線的に低下しているが，新 制教育制度に完全に移行した後の1941年生まれ以降の世代ではほぼ水平に推移してい ることがわかる。次に学歴別のグラフをみてみると, 初等学歴達成者では, まずゆる やかな右下がりの傾向であり, 1956年生まれの世代からは, 若干上昇する傾向にある。 ただしこの世代では高等学校進学率が上昇し, 中卒者が激減しているために, 初等学 
学校教育と戦後日本の社会意識の民主化

歴達成者の数は多くはない (33サンプル)。一方, 中・高等学歴達成者のグラフは 1940 年生まれの世代まではほぼ直線的に低下し，その後の世代ではほぼ水平に推移してい る。そして，1951年生まれの世代以降，高学歴化の影響で中・高等学歴達成者のグラ フと標本全体のグラフが近接していることが指摘できる。生年世代を用いたこの分析 では，後述するように教育制度の移行期にあたる世代が正確に分別されていないた め,グラフの推移から教育制度の新・旧の質的差異を読み解くことは難しい。しかし， いずれのグラフからす1940年以前と，それ以降とでは得点の高低および変動の状況に 差異が見出され，権威主義得点と世代の関連は，単に高学歴化や加齢に起因するので はなく，旧制教育と新制教育の社会意識の民主化効果の違いに基づいていることが予 想される。

図 1 権威主義得点の世代間推移

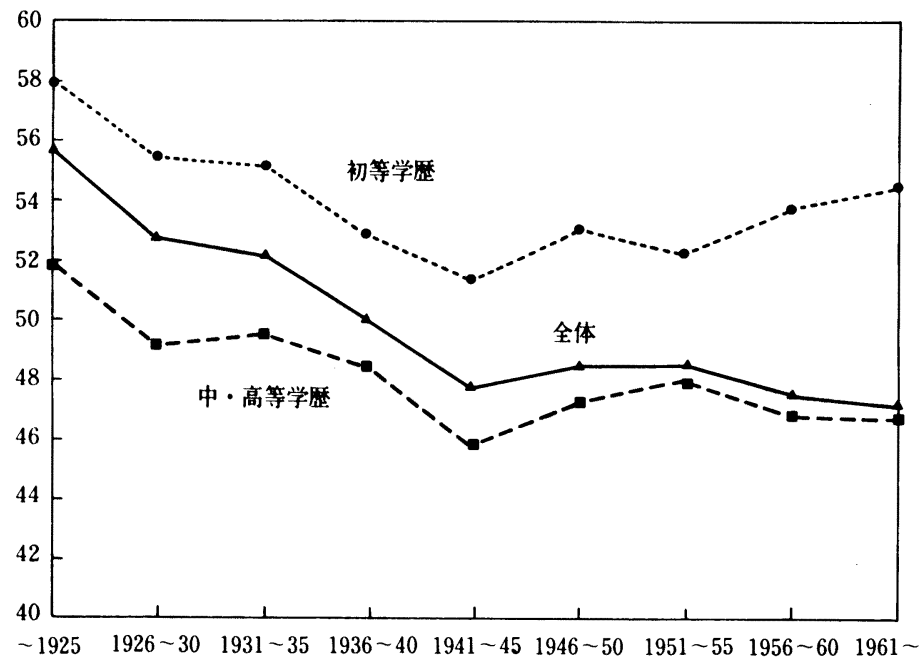

出生年

そこで，標本全体を学校教育の歴史的背景による質的な差異に基づいて以下の 3 つ のグループに分ける。第 1 のグループは戦前の学校教育のみを受けたグループ（以下， 旧制グループとする）である。操作上は最終学歴を旧制（旧制尋常小学校，旧制中学 校，旧制大学など）としている回答者がこの旧制グループを構成する。このグループ は1915（大正 4）年から1934（昭和 9）年生まれまでのおよそ20年の幅広い年齢分布を しており，ファシズム教育が先鋭化する時期（1935年前後）よりあ以前に最終学歴を 
達成した世代から, 第二次大戦末期に学業を中断させられた経験をもつ世代までが含 まれる。そのため厳密にはそれぞれの年龄や進学の程度によって受けた教育の質が微 妙に異なるが，このグループの受けた学校教育の共通の特質を挙げると以下のように なる。

このグループの学齢期は，旧制教育の制度と理念が一連の最終段階を迎えた時期と 重なる。1917年発足の臨時教育会議の「教育ノ効果ヨ完カラシムベキ一般施設二関ス 儿建議」(1919年）は，デモクラシー，社会主義の思潮が高まるなか国民思想を統一し て国民道徳を徹底する必要を強調し, 以後すべての学校令の改革の基調となってお り，ここに「国体明徵」の教育への一歩を確認することができる。その後の教育政策 は，現役陸軍将校の学校配属と軍事教練の実施（1925年）に典型的に現れているよう に, ファシズム教育を進行するものであった（森 1984, 山住 1987）。1920年代後半 から30年代には，教育政策に対する軍のいっそうの介入により，戦時下の軍国主義精 神の練成としての教育が次第に強化されていった（小沢 1984）。ことに1941年に施行 された国民学校令では，「国民学校八皇国/道二則リテ初等普通教育习施シ国民ノ基 礎的練成ヨ以ッテ目的トス」とされ, 初等教育において極端な反民主的価値を植え付 けることが明確な目的とされたことが知られる。1943年から1945年にかけては，授業 を停止しての勤労動員や学徒動員という教育制度の事実上の崩壊を経験している。以 上のようにこのグループは, 天皇中心主義のファシズム的価値を伝達し, 国民を全体 主義体制に総動員することを公然と第一目的とする教育を受けていたことが明らかで ある（久保 1984）。

第 2 のグループは戦時下の学校教育を受け, つまり前述の旧制尋常小学校あるいは 国民学校初等科に入学し, 旧制のいずれかの学校在学中に1947 (昭和22) 年の学制改 革によって新制に移行したグループ（以下，移行期グループとする）である。このグ ループの最終学歴はすべて新制になり, 昭和初期（1925３5年）生まれの場合, 同年 齢でも教育年数が短い場合は上述の旧制グループに分類されるが, 高学歴である場合 はこの移行期グループに分類されることになる(2)。したがってこのグループ構成は生 年での区分と完全には重ならないことに留意しなければならない。このグループの特 性は，戦時中の極端な軍国主義教育を受けた後に，教科書の悬筀りや教職不適格者の 追放などに象徵される価値観の反転を経験したということであろう。そして戦後, 最 あ強力に民主的価值が教育されたグループであるということができるだろう（鈴木 1984, 佐々木 1984)。

そして第 3 のグループは新制の小学校に入学した世代 (以下, 新制グループとする) 
学校教育と戦後日本の社会意識の民主化

である。これは1940年以降に生まれ，現行の六・三・三・四制の新制教育のみを受け た人たちであり，生年によって明確にグループ化される。このグループは, 教育基本 法や学校教育法に基づく，現在まで通じる戦後の民主的な教育のみを受けた世代であ る。また，今後の日本社会に着実に成員を供給し続けるグループであり，「戦後社会」 ではなく現代社会論の镜点からもその動態が注目される。ただし当然のことながら, 戦後の民主主義的教育を受けたという基準で一括したこのグループ内にも，おおよそ 一世代にあたる25年のレンジの年齢分布があり，その間には学校教育の内容に細かな 時代的変镸があるとみなされるだろう。こうした戦後の学校教育の時代的変遷が社会 意識の民主化に及ぼす影慗は，グループ内での権威主義的傾向の年齢による差異とし て検出されることになる。

なお, 各グループのサンプル数は, 旧制グループが318サンプル, 移行期グループが 228 サプル，新制グループが693サンプルである。また各グループの教育機会・教育 達成に関する詳細については, 尾嶋（1990）によって本稿とほぼ一致する分類による 分析が行われているので参照されたい。

次に旧制, 移行期, 新制の 3 グループ別に，教育年数，職業威信スコア（直井優 1979), 年龄を説明変数とし, 権威主義得点を被説明变数とした重回帰分析を行なっ た。これは教育の質についてグループ間に存在する差異をコントロールした上で，グ ループ内での年龄差 (生年世代), 階層的要因, 教育年数の直接効果をみたものと考え ることができる。

まず旧制グループの場合（表 5)，教育年数，職業威信，年齢のそれぞれが有意な効 果を示しており, 教育の量に比例した権威主義剝㴪効果, 成人後の職業経験による権 威主義的（あるいは民主主義的）パーソナリティの形成と, 年齢による効果が検出さ れる。本稿の関心は, 極端な軍国主義的価値観の「刷り込み」を受けたこのグループ において,「諸刃の剣」の相殺効果がどのような結果を残しているかという点にあり, その結果は娳䔞効果を意味する有意な負の値 $(\beta=-.169)$ になっている。この効果は, 旧制の教育達成者間に権威主義得点の学歴による格差をもたらし, 表 4 や図 1 で確認 できるように，旧制初等教育達成者（旧制尋常小学校・旧制高等小学校卒）を現代社 会の他の構成員とはかけ離れた高い権威主義得点のままで取り残す結果を導く要因と なっている。このグループの $60 \%$ 以上がこうした旧制初等教育達成者であることを考 虑すると, 旧制教育制度下の初等教育における軍国主義的国民教化と低い教育達成が 残した影震は，戦後日本社会において決して頊末なあのではなかったことが知られ る。なお,ここで検出された年齢の直接効果は, それが世代による学歴差（高学歴化） 
の影響力をコントロールした上での効果であることから，グループ内の兵役経験など による社会・文化的環境の世代間格差および, 若干の加龄による効果であると解釈で きるだろう。

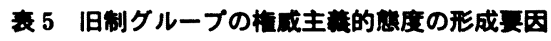

\begin{tabular}{|l|c|c|}
\hline 説明変数 & 偏回㷌係数 B & 標準偏回㷌係数 $\beta$ \\
\hline 教育年数 & $-.609^{*}$ & $-.169^{*}$ \\
\hline 職業威信 & $-.152^{*}$ & $-.178^{*}$ \\
\hline 年 龄 & $0.406^{* *}$ & $0.179^{* *}$ \\
\hline
\end{tabular}

次に移行期グループでは（表 6), 職業威信, 年龄の直接効果は有意ではなくなり, 教育年数による権威主義剝奪効果のみが有意な影整力 $(\beta=-.184)$ を有している。この ことは, 移行期グループ内で成人後の職業経験や生年世代差が権威主義的㑯向の形成 に関与していないことを示しており，次にみる新制グループにも同様にいえることだ が, 権威主義的傾向の形成メカニズムは大きく学校教育に依存しており, 旧制グルー プとは明確に異なっていることを指摘することができる。

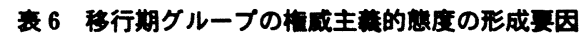

\begin{tabular}{|c|c|c|}
\hline 説明变数 & 偏回㷌係数 B & 標準偏回㷌係数 $\beta$ \\
\hline 教育年数 & $-.794^{*}$ & $-.184^{*}$ \\
\hline 職業威信 & 0.021 & -.004 \\
\hline 年 龄 & 0.233 & 0.048 \\
\hline
\end{tabular}

さらに新制グループでも同様に（表 7), 教育年数の効果 $(\beta=-.280)$ は有意である が, 職業威信, 年齡の効果は有意ではない。またこのグループ内においては権威主義 得点の世代間格差が単相関レベルでもみられなかったことから(3)，戦後25年という期 間において，学校教育による社会意識の民主化効果の䖯勢に，民主化の伸長あるいは 右傾化という趁勢は見出せない。したがって，学校教育を取り巻く環境がこの間に変 遷したことは認めるとしても，そこから生み出されるアウトプットには，ほとんど変 質は認められないといえる。

最後に, 本稿の議論の焦点である学校教育による社会意識の民主化効果の䖯勢を検 討する。これは，権威主義剝蒘効果を 3 つのグループ間で比較することによって可能 となるだろう。権威主義剥隻効果の比較は, 偏回帰係数 B の大きさ, すなわち教育年 数 1 年あたり権威主義得点が何点低下するかをグループ間比较することによって行な 
学校教育と戦後日本の社会意識の民主化

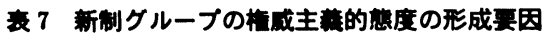

\begin{tabular}{|l|c|c|}
\hline 説明変数 & 偏回㷌係数 B & 標準偏回㷌係数 $\beta$ \\
\hline 教育年数 & $-1.070^{* *}$ & $-.280^{* *}$ \\
\hline 職業威信 & 0.010 & 0.012 \\
\hline 年 齡 & -.065 & -.048 \\
\hline
\end{tabular}

$\mathrm{R}^{2}=.073 * *$ “は $5 \%$,**は1\%水準で有意な值を示す。

うことができる。表 5 7 に示されているとおり, 偏回帰係数 B は旧制グループで609, 移行期グループでは-.794, 新制グループで-1.070となっている。したがって, 学 校教育による権威主義剝傚果は，旧制教育を 1 とすれば，移行期では 1.30 倍，新制 教育では1.76倍とほぼ線形に增加していることが明らかになる(()。

\section{7. 䛨論}

これまでの分析によってわれわれは，以下の結論を得た。

(1) 標本全体において権威主義的傾向と年齢の間にみられた関連は, 主として学校 教育制度の新・旧に起因するものであり，新制世代内では年齢と権威主義的傾向 に直接の関連はみられない。

（2）学校教育の民主化機能は旧制教育，移行期，新制教育之漸増し，旧制教育と新 制教育では約1.8倍の格差がみられる。

（3） 戦後の学校教育による社会意識の民主化機能は，25年間一定して維持されてき た。

このうち(2)の結果については，学校教育による柔軟な発想や判断力の育成，民主主 義的価値観の伝達，そして権威主義的教育条件の低い水準での維持，などが要因とし て考えられる。しかしながら、これらのメカニズムの詳細を明らかにすることについ ては，成人の意識の分布状況からの事後的推測という方法では限界があるだろう。ま た(3)の結果については，戦後の 25 年間では学校教育の民主化機能が高まっていないこ とが指摘できるが，図 1 から明らかになったように，戦後の着実な高学歴化の趨勢す なわち，高校進学率，大学・短大進学率が高まることによって，その世代の民主主義 的社会意識はやはり学校教育によって形成され続けてきたということができるだろ う。つまりこの間，学校教育の質の变容ではなく教育年数の増加によって社会意識の 民主化の趣勢はゆるやかながらも維持されつづけているのである ${ }^{(5)}$ 。

ここでみてきた学校教育の質の変容と社会意識の民主化の関係は, 旧制教育を受け た世代の人口構成上の「退出」, 高学歴化, 学歴の平準化という学校教育に関連する社 
会変動が, 単に社会移動研究や学歴社会論などの構造的研究にとどまらず, 社会意識 論にも少なからぬ影整力をもって接続されうることを示している( ${ }^{(8)}$ 。

デュルケーム（訳書 1976）は, 教育の目的を, 社会生活を営む上で次世代に要求 される身体的・知的・道徳的諸状態の継承に求める。また, パーソンズ（訳書 1973） は, 学校教育の機能として人員の選別・分配と並んで, 知識・技能の習得, 道徳的価 値伝達を要素とする社会化を挙げる。いずれにおいてす, 当該社会に共通する価値の 伝達が，学校教育の本質的かつ第一義的で無視できない機能であるとみなされてい る。ところが，教育社会学における計量研究では，学校教育の人材の配分機能に多く の関心が向けられてきたため, 教育年数はその象徽的意味に注目した学歴としてのみ 解釈され, 次世代の社会意識の形成主体としての機能が十分には検討されてこなかっ たように思われる。学校教育は決して「無色透明」な象徵ではない。それゆえに，そ の中身をブラック・ボックス化した再生産や社会移動の媒介項として理解されるだけ では決して十分とはいえないだろう。

本稿ではこの学校教育の実質的な機能に焦点を絞って議論を展開してきた。その結 果得られた結論は, 決して発見的なものではなく，むしろ至極あたりまえに聞こえさ えする。だが，「戦後日本社会においては民主主義的な教育政策が実施されたうという 歴史的事実の指摘と，「戦後の民主主義的な学校教育によって社会意識が民主化した」 という本稿の分析結果は全く同じことを意味しているわけではない。社会意識の民主 化は, 教育制度の改革をもって一朝一夕に完了するわけではないのである。この問題 に関して現代の社会意識論の視点から関心が持たれるのは，いま現在見出される「結 果」である。本稿でみてきたように，学校教育を受けたのははるかに昔のことであっ ても, その個人が当該社会の構成員として社会意識の分布を構成する限り, 当時受け た教育の残㳯は存在しつづけている。冒頭に述べたようにいま, 戦前・戦中の軍国主 義教育が社会意識に残した賃跡は, 戦後 50 年の時間的経過による人口学的退出効果 で, ようやく消え去ろうとしている。われわれは, 変更不可能な過去の出来事が現代 社会の社会意識の分布を規定してきたという事実を確認し，その上でこれからの社会 構造を構成する現下の教育を検討する立場にある。現在教育を受けている世代が退出 するまでにさらに50年の年月を要するのである。

〔付記 1〕データ解析は吉川，劧共同で行ない，冒頭から「民主主義的社会意識 の測定」までの草稿をが，「分析」から「議論」までの草稿を吉川が分担作 成した。その後両者の協議の上, 修正した。 
学校教育と戦後日本の社会意識の民主化

〔付記 2〕本研究は1995年 SSM 調查研究の一環として行なわれたあのである。 データの使用および結果の発表にあたって, 1995年 SSM 調查研究会の許可 を得た。

〈注〉

（1）1985年 SSM 調査の詳細については直井・盛山（1990）を参照されたい。なおこの 調查設計では，成人女性に対する権威主義的態度の調査項目は含まれていない。

（2）どの学歴水準の旧制教育をどれだけ受けたか，という基準でこのグループをさら に精緻に分類することも考えられるが，本稿では学校教育による社会意識の民主化 の機能の变遷を概略として把握することを目的としているため,こうした検討は行 なっていない。

（3）この新制グループについては，現代社会の社会意識の民主化の様態として記述的 数值に関心がもたれるので，下に相関行列を示しておく。このグループでは年齢 （世代）と権威主義得点の間には単相関も見出せない。

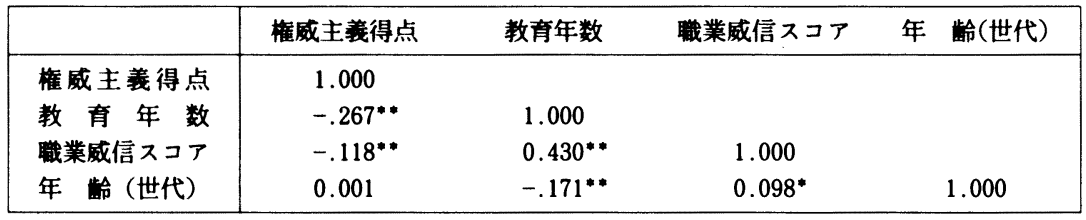

*は $5 \%$ 水準, ** は $1 \%$ 水準で有意な値を示す。

（4）こうした結論に対する対立仮説として，卒業後の社会的な様々な経験によって教 育の効果が消えて, 権威主義的傾向が増大するため, 年齢が高い, つまり社会経験 が豊富であるほど権威主義的になるというものが考えられるが，一旦形成された知 的能力や判断力は一生を通じて簡単には低下しないことと, 戦後日本社会におい て, 学校教育の効果を凌ぐような強力な権威主義的価値伝達エージェントが存在し たとは考えにくいことから否定されうると考えられる。この点については，例えば 10年を経過した1995年時点で同グループの権威主義得点にいかなる变化が見られた かをコーホート分析で明らかにすることによって確証しうるが, これは今後の課題 としたい。

（5）学校教育による権威主義的価值の伝達機能を全くなくしてしまえば，社会意識の 民主化はより効率的に進行するのではないかという考えが生じるかもしれない。し かし, 当該社会の共通の道徳的価値を伝達するためには学校教育では, なんらかの 
権威を肯定せざるをえないし，知識・技能の伝達のために，教師が自らの指導者と しての立場を権威付けながら学級集集団を運営していく必要もあるだろう。そのた め, 明らかな弊害に見える学校教育による権威主義的価値の付与の効果を, 完全に 消滅させることは事実上不可能であろう。そこで，学校教育による社会意識の民主 化機能をさらに増大させるためには，知的能力の養成をさらに効果的に進めること と，必要以上の権威主義的価値を付与しないことが鍵となると考えられる。

（6）ここでの結果は，例えば投票行動を研究するうえで政治社会学が基盤としている 潜在的意識構造の近年の複雑な变容（綿貫 1986, 宮野 1995）に学校教育に関す る䟇勢からの説明の糸口を提供しうるのではないだろうか。

\section{〈引用文献〉}

Adorno, T. W. et al. 1950, 田中義久 ·矢沢修次郎・小林修一訳（部分訳）『権威主 義的パーソナリティ』青木書店 1980。

Durkheim, Émile 1922，佐々木交賢訳『教育と社会学」誠信書房 1976。

日高六郎 1960,「『旧意識』とその原初形態」『現代イデオロギー』勁草書房, 229-259 頁。

城戸浩太郎 1970,「イデオロギーとパーソナリティ」「社会意識の構造」新曜社，339頁。

城戸浩太郎・杉政孝 1954, 「社会意識の構造」『社会学評論』4, 74-100頁。

吉川 徹 1996, 「学校教育の諸条件と青少年の社会的態度形成」「社会学評論」184, 428-442頁。

Kohn, M. L. and C. Schooler 1983, Work and Personality, Ablex.

久保義三 1984, 「国民学校教育における矛盾の諸相」『講座日本教育史 4 現代 I / 現代I」第一法規，153-175頁。

宮野 勝 1995, 「日本の有権者の变化」「中央大学文学部社会科学科紀要」5, 33-47 頁。

森 秀夫 1984, 『日本教育制度史』学芸図書。

直井 優 1979, 「職業的地位尺度の構成」富永健一編「日本の階層構造」東京大学 出版会, 434-472頁。

直井 優 1987,「仕事と人間の交互作用」三隅二不二編『働くことの意味」有斐閣, 103-144頁。

直井 優・盛山和夫 1990 ,『現代日本の階層構造 1 社会階層の構造と過程」東京大 
学校教育と戦後日本の社会意識の民主化

学出版会。

直井道子 1988,「職業階層と権威主義的価値意識」『1985年社会階首と社会移動全国 調查報告書 第 2 巻 階首意識の動態』1985年社会階層と社会移動全国調査委 員会。

尾嶋史章 1990, 「教育機会の䟇勢分析」, 菊池城司編『現代日本の階層構造 3 教育之 社会移動」東京大学出版会, 25-55頁。

大塚久雄 1948, 『近代化の人間的基礎」白日書院。

小沢 喜 1984,「教育蕃議会による国家総動員体制下の教育改革」『講座日本教育史 4 現代 I / 現代 II 」第一法規，45-69頁。

Parsons, Talcott 1964, 武田良三監訳『社会構造とパーソナリティ』新泉社 1973。 佐々木亨 1984, 「学校教育法の成立」『講座日本教育史 4 現代 I/現代 II 第一法 規, 332-356頁。

白倉幸男・岩本健良 1990 ,「現代の階首構造における自営業の位置」, 直井優・盛山 和夫編『現代日本社会の階首構造 1 社会階首の構造と過程』東京大学出版 会, 109-126頁。

鈴木英一 1984, 「連合国の対日占領教育政策」『講座日本教育史 4 現代 I / 現代 II」第一法規，226-253頁。

山住正己 1987, 「日本教育小史』岩波新書。

綿貫䜅治 1986, 「社会構造と価値対立」, 綿貫变治・三宅一郎・猪口孝・蒲島郁夫編 『日本人の選挙行動」東京大学出版会, 17-37頁。 